\title{
Strategy of Strengthening Food and Beverage Industry in Indonesia
}

\author{
Ragimun $^{1}$, Sri Widodo 2 \\ ${ }^{1}$ Fiscal Policy Agency, Ministry of Finance of Indonesia \\ ${ }^{2}$ Economics Faculty of Dirgantara Suryadarma University, Jakarta, Indonesia \\ ragimun@gmail.com,wiedsa82@gmail.com
}

\begin{abstract}
The food and beverage industry has an important role to play in the Indonesian economy. This industry's contribution to the GDP of the non-oil and gas industry reaches almost 34 percent and absorbs a lot of labor. The purpose of this paper is to analyze the strategy of strengthening the food and beverage industry which can improve the performance and competitiveness of Indonesia's food and beverage industry sector. The approach used is a descriptive approach. The results of the analysis show that for some food commodities have a low competitiveness, while the beverage industry which is dominated by soft drinks and alcoholic beverages, Spirits drinks and Beer has an increasing trend. To improve the competitiveness and performance of Indonesian food and beverage products, the government has carried out several policies, but not yet optimal. The strengthening effort that must be made by the Government is to increase exports to nonoptimal markets (Untapped Market Countries). In addition, for the development of small and medium industries, the industrial sector also needs fiscal incentives as well as increased industrial technology capabilities.
\end{abstract}

Keywords: Strengthening the food beverage industry, Competitiveness, Export performance.

\section{Introduction}

The food and beverage industry currently has a significant contribution to the Indonesian economy. In recent years the growth and investment value of this sector has continued to increase. The contribution of food and beverage to the Gross Domestic Product (GDP) of non-oil and gas industry reached 33.6 percent in the third quarter of 2016. In 2016 the food industry experienced growth of 6.95 percent, and contributed, 4.73 percent to GDP. This industry also contributed to exports of USD 456.6 million, absorbing a workforce of more than 4 million people. In fact, the Indonesian food and beverage industry has the opportunity to win competition in the Asean Economic Community (AEC) region through cooperation between the Government and industry to improve competitiveness (Ministry of Industry, 2017). The growth of the food and beverage industry was largely due to the realization of new investments, an increase in people's purchasing power, and the growth of Indonesia's population with an average of 1.49 percent per year in the last 10 years (Statistics Indonesia, 2018). Indonesia, as the world's fourth most populous country and growing middle class, has increasingly attracted the food and beverage market. However, going forward, the challenges and obstacles of the Indonesian food and beverage industry will continue to increase. At present, with the entry into force of the free market of the Asean Economic Community (AEC), the competition of the food and beverage industry among ASEAN countries has become tighter. Therefore, Indonesia's food and beverage industry needs to strengthen competitiveness so as to create a healthy business climate.

Besides that, mutual cooperation between ASEAN countries is needed as well by striving to create a conducive, business climate. Global Competitiveness Report Index Data 2016-2017 Ranking, Indonesia's competitiveness is ranked 41 out of 138 countries. This ranking is below Singapore which is in position 2, Malaysia position 25, and Thailand is in position 34. In the food and beverage industry, among ASEAN countries, the main competitors are Thailand and Malaysia (WEF, 2017). The food and beverage industry sectors of the two countries are well integrated, starting from raw materials to post-production. Thailand, currently has implemented facilities and infrastructure of its food and beverage industry by making industrial clusters so that the economies of scale of Thai products become larger. The growth of the food and beverage industry in this country is very rapid this is due to the habits of the Thai people who prioritize the consumption of food products and beverages that are more natural, varied, and hygienic. The performance of the food and beverage industry in Indonesia continues to increase at this time, but there are several major problems in this sector. Among others, investment opportunities that have not been optimal, have not been integrated between the upstream and downstream sectors of the food and beverage sector, tighter competition among ASEAN countries and opportunities for the fulfillment have not been met; fulfill domestic 
and foreign food and beverage demand. Therefore, it is necessary to conduct a study to find out the strategy of strengthening the Indonesian food and beverage industry among ASEAN countries.

\section{Literature Review}

Basically the food and beverage industry is divided into the food industry and beverage industry. The food industry is currently growing but not as fast as the growth of the beverage industry. The prospect of the beverage industry currently still has challenges and opportunities, especially in the Southeast Asian markets (Perumal, 2017). In addition to competition between manufacturers, competition also seizes markets or consumers. As stated by Richard Haffner. According to him, based on consumer habits of consuming soft drinks, it is divided into several consumer groups, including:

- The growth of consumption of soft drinks is currently saturated, especially in the markets of developed countries such as North America, Western Europe and Australia.

- Growth in consumption of soft drinks in developing countries (Developing Market Countries) such as East Europe and Latin America which have reached 70 percent of the level of consumption in the Developed Market Countries.

- Growth in consumption of soft drinks in countries that have not been utilized optimally (Untapped Market Countries) such as countries in the Asia Pacific, Africa and countries in the Middle East region which currently have relatively large potential because only 10 percent of all drink needs.

If you see the amount of consumption per capita per year in the three soft drink product market areas, it can be seen that for untapped soft drinks, the potential for market penetration is still large, because it is only around 10 percent. This area is still dominated by tap water and branded bottled water. For milk / dairy drinks, it is still relatively small. Likewise hot drinks. For the market area of developing markets countries, tap water and branded still dominate, soft drinks also continue to increase including milk / dairy drinks and hot drinks. As for the developed market countries, the soft drinks market has reached a saturation point, as well as tap water and branded, milk (dairy drinks) and hot drinks. The concept of competitiveness is widely used to measure the superiority of a country's products against competitors. A country is said to have competitiveness or competitive advantage over its countries if the country has a greater market share than its competitors (Wibowo, 2010). Competitiveness can be interpreted from the demand and supply side. The demand side means that the product being marketed must have attributes that are in accordance with the demands and desires of consumers. While from the supply side is the ability to compete by responding to changes in product attributes that are demanded or desired by consumers. The concept of competitive advantage was developed by Porter (2008), starting from the reality of national trade. According to Porter, there are 4 main factors that determine competitiveness, namely the first condition factor. In addition, demand factors are related to competitive supporting industries, as well as structural conditions, competition and industry strategies. There are two factors that influence the interaction between the four factors, namely opportunity and government factors. The relationship of these factors together form a system in increasing competitive advantage called Porter's Diamond Theory. This system can be seen in Figure 1. 


\section{Figure 1: Porter's Diamond Theory}

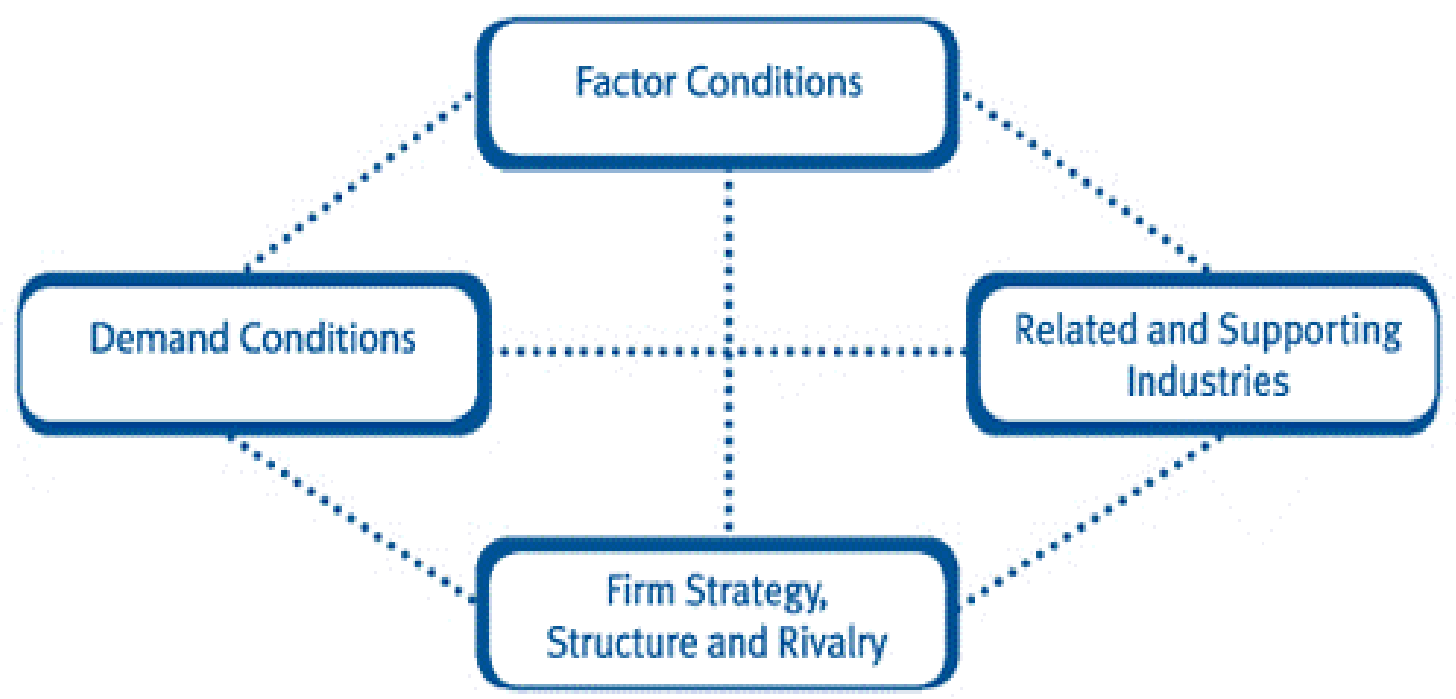

Source: Porter's Diamond Model, https://kfknowledgebank.kaplan.co.uk/porters-diamond-model-

In the factor conditions, a nation's resources are a very important production factor in order to win the competition. Demand conditions greatly affect the determination of competitiveness and quality of demand. While the existence of related and supporting industries affects global competitiveness. In order to maintain and maintain competitive advantage, it is necessary to maintain and always coordinate with suppliers to maintain the value chain. In the factor of firm strategy, structure and rivalry, the existence of reliable local competitors is the driving force to put pressure on increasing competitiveness. Likewise, strategies that can strengthen competitiveness in order to improve the performance of the Indonesian food and beverage industry must also be sought. The structure of the company and industry will determine competitiveness by making improvements and innovations.

\section{Research Method}

In this study a qualitative descriptive approach is used, which emphasizes more on the discussion by means of strategies for strengthening the Indonesian food and beverage industry. This approach aims to explore and illustrate the performance and strategies that can be taken to strengthen the competitiveness of the Indonesian food and beverage industry in the international market. Sources of data and information used are data from Statistics Indonesia (Central Statistics Agency), the Ministry of Industry, the Ministry of Trade, Food and Beverage Association and various relevant data sources.

\section{Results and Discussion}

Indonesian Food and Beverage Industry Performance: Several industrial sectors in Indonesia experienced quite high growth, one of which was the food and beverage industry sector. This industry opportunity is huge. In the future, this industry will become a mainstay for increasing aggregate economic growth in Indonesia. This can be seen from the trend of the contribution of the food and beverage industry to the national GDP. The highest growth in the non-oil and gas industry sector in 2015 was achieved by the Metal, Computer, Electronic, Optical and Electrical Equipment sectors with a growth of 7.83 percent. Then followed by the Food and Beverage sector with a growth of 7.54 percent. While the Machinery and Equipment Industry sector grew by 7.49 percent, as well as the Chemical, Pharmaceutical and Traditional Medicine sectors, which grew by 7.36 percent (Statistics Indonesia, 2018). The food and beverage industry sector currently has an important contribution to the Gross Domestic Product, especially the non-oil and gas industry sector. The contribution of the pharmaceutical industry (including the tobacco processing industry) to the GDP of the non-oil and gas industry in the third quarter of 2015 was 31 percent. While the growth rate 
of the food and beverage industry in the third quarter of 2015 reached 6.95 percent or higher than the growth of the non-oil and gas industry by 5.21 percent and GDP growth of 4.73 percent. The food and beverage industry in 2016 also experienced growth of between $7.4-7.8$ percent. The business opportunities for the food and beverage industry are still quite large. From the data on the achievement of the following types of food there are several items that have high prospects. For the top five food products in the Asia Pacific region, many are dominated by Grain Mill Products, such as bread made from wheat.

Then the second, is vegetable and animal oil (vegetable and animal oil and fats). Third, is meat and meat products. Whereas number four and five are coffee, tea, spices and ready-to-eat food (coffee, tea, spices, and ready meals) and pet food (Pet food and animal feeds). In addition to the above products, judging from the development and achievement of food products in the Asia Pacific, fish and fish products. This opportunity for Indonesia is very large because of many factors. Aside from Indonesia, it has a vast sea resources and also a large potential source of terrestrial fish. Besides many biological sources that are currently not widely exploited. Especially for capture fisheries the potential of fisheries in Indonesia is very abundant which is expected in the future to be the leading sector of the national economy. For that potential must be utilized optimally and sustainably. Opportunities for development of the Indonesian fisheries business have very high prospects. Potential marine and fishery resources that can utilized is estimated to reach more than USD 82 billion per year. (D.S. Maradong, 2016) Not including the potential of products from fish and products from fisheries and marine resources such as seaweed. Other achievements of the Asia Pacific food industry are vegetable products, potatoes and fruits. The potential of food products such as fruits in Indonesia is also very high. Research shows that Indonesian fruit commodities tend to have competitiveness for products based on low technology and based on natural resources. The results of this study found that Indonesia has a low level of competitiveness in the export of five fruit commodities, namely pineapple, papaya, banana, mango, and orange, indicated by the total Revealed Comparative Advantage (RCA) which is still below one.

Indonesia has an average RCA for exports of the five lowest fruit commodities compared to Malaysia, the Philippines and Thailand (Hanani et al, 2009). The beverage industry for the Asia Pacific region for the years 2015-2016 is dominated by soft drinks and alcoholic drinks, which value reaches more than 200 billion US dollars. Third, Spirits drinks while Beer ranks fourth. The population of Indonesia, which amounts to more than 250 million people at present, turns out that the level of Indonesia's soft drink consumption is the lowest compared to ASEAN countries. For carbonated drinks, 33 liters per capita per year, while bottled water is 53 liters per capita per year, and other drinks are lower. This makes a big opportunity for the beverage industry because of the low consumption of soft drinks in Indonesia. Compare Thailand with 89 liters per capita per year, Singapore 141 liters per capita per year, Philippines 122 liters per capita per year. In 2016 Indonesia set a target of 100 liters per capita per year for the average soft drink. If Indonesia's population growth in 2016 reaches more than 250 million people, the target of the soft drink industry is to consume 25,250 million liters per year (Ministry of Industry, 2016). One of the industrial sectors that can be a mainstay of Indonesia in the future and still has the prospect of being developed is the food and beverage industry. Enforcement of the Asean Economic Community (AEC), Indonesia is required to have a domestic competitive food and beverage industry so as not to become a market for neighboring countries.

This is because it is supported by abundant and quite potential natural resources from the agriculture, fisheries, marine, livestock, plantation and forestry sectors. For this reason, a strong commitment from all stakeholders is needed in supporting these strategic steps, such as increasing product standards through the application of SNI, improving the quality of human resources through the application of the Indonesian National Work Competency Standards, accelerating infrastructure development, and developing research and development (R\&D). It also needs to increase the use of domestic products, harmonize central and regional policies, and simplify the licensing and investment bureaucracy. There needs to be closer cooperation in increasing the competitiveness of the domestic industry. To increase the competitiveness of the food and beverage industry it can be formed from quality products and a business climate that favors growth. Development of the food and beverage industry is very meaningful for the community, because it is not only useful to meet the needs of processed foods and beverages in the country, but also plays an important role in increasing the added value of primary agricultural products. Therefore, the food and beverage industry will also be able to become the main driver of the economy in various regions in Indonesia and encourage the growth of related industries. Also important is the conducive investment climate needed to encourage the 
food and beverage industry sector in Indonesia. At present there are several multinational companies that invest in the food and beverage industry sector in Indonesia. One of them is investors from European countries who invest specifically in food beverages in Indonesia, which include:

\section{Table 1: Investors in European Food Beverages in Indonesia}

\begin{tabular}{|c|c|c|c|}
\hline No & Country & Company & Procuct/Business \\
\hline 1 & France & $\begin{array}{l}\text { GroupeDanone, } \\
\text { Mane }\end{array}$ & Food products and flavored products \\
\hline 2 & Ireland & Kerry Group & International supplier of good ingredients and flavour \\
\hline 3 & Italy & Perfetti Van Melle & Biscuit product (Confectionery manufacturer) \\
\hline 4 & Netherlands & $\begin{array}{l}\text { Unilever, Friesland } \\
\text { Campina, Kievit, } \\
\text { DSM, }\end{array}$ & $\begin{array}{l}\text { Multinational consumer goods company, Dutch milk cooperative } \\
\text { (dairy cooperative),food ingredients, multinational life sciences } \\
\text { and materials sciences-based company, his global end markets } \\
\text { include food and dietary supplements, personal care, feed, } \\
\text { pharmaceuticals, medical devices, automotive, paints, electrical } \\
\text { and electronics, life protection, alternative energy and bio-based } \\
\text { materials. }\end{array}$ \\
\hline 5 & Sweden & Tetra Pak & Multinational food packaging and processing company \\
\hline 6 & German & BASF & Food products (food ingredients) \\
\hline 7 & Denmark & $\begin{array}{l}\text { DuPont Danisco } \\
\text { A/S }\end{array}$ & Food products, enzymes, and bioproducts \\
\hline 8 & Switzerland & Firmenich & Flavoring products \\
\hline
\end{tabular}

Source: Richard Haffner, Euromonitor, 2010

Investments from companies above only produce food and beverages that already have international brands. But local companies have not been able to enter the international market. Therefore, the challenges and opportunities are besides increasing investment in the food and beverage sector in Indonesia, as well as strengthening the competitiveness of the food and beverage industry in Indonesia. The results and findings can be seen that the competitiveness of Indonesian food and beverage products still needs to be improved in order to win competition in the current era of globalization. One of them is an increase in efficiency and quality which still needs serious attention (Adji Ardi, 2012). The government has basically tried to take steps and strategies to increase the competitiveness of the food and beverage industry. There are 10 strategic programs, among others, namely: (1) Ensuring the availability of quality raw materials, quantity and continuity through coordination with relevant agencies and partnerships and integration from the upstream and downstream sides supported by adequate infrastructure; (2) Preparing skilled and competent human resources in the food and beverage industry through industrial training and mentoring; (3) Enhancing the mastery and development of food industry technology innovation through integrated research and development. Furthermore, (4) Increasing the efficiency of processing and product quality assurance through the application of Good Hygiene Practices (GHP), Good Manufacturing Practices (GMP) and Hazard Analysis and Critical Control Points (HACCP), certification of Indonesian National Standards (SNI) and halal, certification other qualities, as well as assistance in processing food and beverage products / machinery; (5) Coordinating the development of logistics systems to improve.

The efficiency of production and distribution of food and beverage products; (6) Facilitating the release of Value Added Tax (VAT) on the processing of food and beverages with small added value. Seventh (7), Facilitating access to competitive financing for small and medium scale food and beverage industries; Eighth (8) Increasing international industrial cooperation for technology transfer, increasing investment and mastering export markets; Ninth (9) Promote and expand the market for food and beverage industry products at home and abroad; and Tenth (10) Facilitating Small and Medium Enterprises (SMEs) in the framework of implementing halal labels. Next to the program, the food and beverage industry still has challenges to be faced, especially for food and beverage businesses. On the side of raw materials, the supply of 
sugar and salt is needed a long-term solution so that business people get the certainty of the supply of sugar and salt, considering that the two ingredients are still partially imported which will increase production costs. On the other hand, in the future we will continue to strive to reduce logistics costs which have so far been inefficient. Some of the proposals for the establishment of the Bonded Logistics Center will soon be realized to help the mamin industry fulfill its raw material needs by purchasing vendors' raw materials or rescuers in the Bonded Logistics Center. At present in Indonesia, the performance of some soft drinks includes (1) bottled drinking water drinks that have a market share of 84 percent, (2) carbonated soft drinks, have a tendency to stagnate, both because of many other beverage choices, and because of issues health problems due to consuming carbonated drinks, the market share is 3.6 percent. If you see the growth trend of fast food soft drinks in Indonesia in the form of RTD (Ready to drink) Tea, RTD Carbonates, RTD water, and others (Others) can be seen in Graph 1 as follows.

\section{Graph 1: Fast Food Soft Drink Growth}

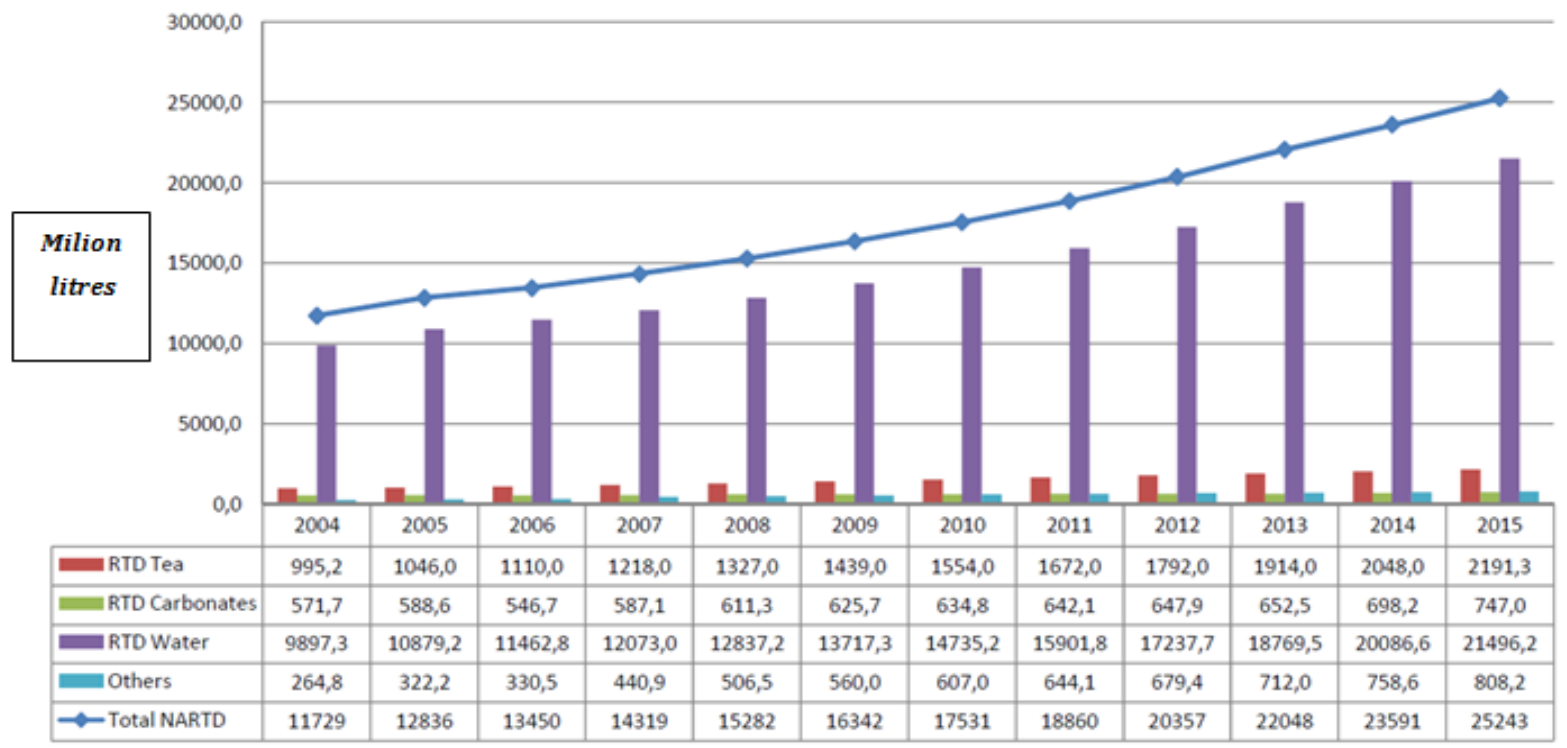

Source: Euromonitor is processed by ASRIM (Soft Drink Industry Association), 2016

The assumption of a minimum growth rate without considering the level of innovation both in type, packaging, brand and price. When the beverage industry is categorized into 4 major groups, namely RTD (ready to drink) tea, RTD Carbonates, RTD Water and other beverages, the growth of this industry has an increasing trend. Until 2015 the total RTD was 25,243 million liters. When compared to Indonesia's population of 250 million, Indonesia's per capita RTD reaches 100 liters per capita per year (Poeradisastra, 2012).

Efforts to Strengthen the Food and Beverage Industry in Indonesia: The optimism of the export performance of Indonesia's food and beverage industry will continue to improve. This belief was driven by projections of improvement in the global economy and the Asean region which made the food and beverage manufacturing industry move positively as well as increasing domestic production. Some efforts that can improve the performance of national food and beverage include the following:

- The need for small and medium industry development programs including the food and beverage industry. The efforts in this program are in line with policies and programs for Empowering Cooperatives and Micro, Small and Medium Enterprises. The related programs are mainly the Entrepreneurship Development Program and SME Competitive Advantages. The purpose of this program is to make small and medium industries as the national industrial base. 
- The need for programs to improve the technology capabilities of the food and beverage industry. The purpose of this program is to improve the ability of the industry to create, develop, and apply knowledge both in the commercialization of $\mathrm{R} \& \mathrm{D}$ results, the design of new products, and the production process in the food and beverage sector. In order to encourage the food and beverage industry, it requires the development and application of process technology, product and design technologies, the main activities of the government in the future include: 1. Increasing the support of industrial technology discovery and development activities in the form of tax incentives, technology insurance especially for small businesses , middle, and cooperative; 2 . Encouraging the development and utilization of production management that takes into account the balance and carrying capacity of the environment, as well as environmentally friendly production techniques (clean production); 3. Expansion of the application of manufacturing industry product standards that is in compliance with international standards 4. Increasing the capacity of the institutional network for measurement, standardization, testing, and quality (MSTQ / measurement, standardization, testing, and quality) 5. Development of technology-based industrial clusters and 6 Revitalizing R \& D policies and institutions in the production sector to be able to accelerate the effectiveness of partnerships between industrial R \& D and government R \& D institutions; and optimize the utilization of national technology resources spread across various government R \& D, universities, private institutions, and individual experts.

- The need for a structuring program for the structure of the food and beverage industry. The aim is to improve the structure of the national food and beverage industry both in terms of market control concentration, and a network of suppliers of raw materials and supporting materials, components, and intermediate goods for downstream industries. In the initial stages of national industrial development, industrial resources and industrial entrepreneurship are still very scarce, so national policies really need to improve monopolistic practices.

- The need to increase the infrastructure capacity of the food and beverage industry. This is done in order to anticipate increased capacity utilization, growth of new investment, the spread of food and beverage industry activities both in Java and outside Java, and to increase the production base of this sector usually in rural areas, so that the acceleration of infrastructure development becomes very important.

- To strengthen the structure in facilitating the establishment of a network of downstream industry suppliers, the government immediately implements key activities which include: 1 . Development of production potential information systems from supporting industries and the pharmaceutical industry; 2. Encouraging the establishment of supporting industry partnerships with the food and beverage industry; 6) Continuing to develop supporting industries in the food and beverage industry; 4. The need for institutional capacity strengthening of skilled industrial labor providers, especially in accordance with the needs in the food and beverage industry; 5. Facilitating the development of food and beverage industry cluster infrastructure, especially the food and beverage industry technology infrastructure, and 6. Facilitating and coordinating the development of food and beverage industry cluster growth centers outside Java, such as the Eastern Indonesia Region.

- The implementation of administrative optimization and tax incentives. Efforts to stimulate an increase in the production base, productivity and investment in the food and beverage industry sector are highly dependent on the government's commitment to facilitate business efficiency. Especially related to the role of facilities and public service providers, especially efficient taxation. Development program programs that have close links with increasing State Finance Receipts include organizing tax reforms and customs reforms, as well as the Financial Institutional Development Program which has steps to provide support for increasing SME lending in the food and beverage industry and sectors. other supporting sectors.

- To encourage an increase in the performance of Indonesian food and beverages, one of them is to provide market access to the food and beverage manufacturing industry to non-traditional markets. The market in question is potential country markets such as markets in Developing Market Countries like Latin America and Eastern Europe. These countries still need food and beverage manufacturing products. Besides the markets in countries that have not been utilized for the marketing of food and beverage manufacturers (Untapped Market Countries) such as countries in the Asia Pacific, Africa, countries in the Middle East region have great potential due to the volume of soft drinks when this is 
only 10 percent of the total beverage needs. Especially for the non-traditional Middle Eastern market, market opportunities to enter this area include quality products and have obtained a "halal" label.

- Other support is the provision of investment incentives (tax holiday, tax allowance), raw material supply facilities, and infrastructure development in supporting connectivity to improve the effectiveness and efficiency of distribution of raw materials and manufactured products. Some things need to be addressed include logistical infrastructure, port capacity, logistics cost policies, national energy policies such as fuel oil, gas, basic electricity tariffs, and others.

- Re-synchronizing regulations related to the overlapping food and beverage industry. Likewise, regulations that are in the process of change also consume a lot of time and energy. Such regulations regarding Draft Government Regulation on Waste Management, Hazardous and Toxic Waste, Halal Product Guarantee Bill, Draft Bill on Pharmaceutical Supply Control, Medical Devices, Household Health Supplies and Processed Food (Food has been issued), and discourse on imposition of excise on carbonated beverages.

- Realizing the ASEAN countries' agreement with China, forming the ASEAN-China Food Industry Cooperation Committee in the food and beverage industry sector which was agreed in Kunming China on June 6, 2014 which was held by the 5th ASEAN-China Industry Cooperation Kunming Conference including the establishment of the China ASEAN Business Association (CABA) which aims to facilitate the business world, as well as provide consultation and complete information about food and beverages.

\section{Conclusion and Recommendations}

Opportunities for the performance of the food and beverage industry have the potential to continue to improve. The growth of other drinks that tend to go up is Isotonic Drinks, Fruit Juice Drinks and other drinks with fruit flavor (Kemenperin, 2012). This belief is driven by projections of an improving global economy that makes the food and beverage manufacturing industry move positively and increase domestic production to be able to compete with fellow Asean countries. To improve the export performance of Indonesian food and beverage products, it still has market opportunities. These markets include markets in countries that have not been utilized for marketing of food and beverage manufacturers such as developing countries, countries in the Asia Pacific, Africa, countries in the Middle East that have great potential. because the volume of soft drinks (ready-to-eat) currently only reaches 10 percent of the total beverage needs. Especially for the nontraditional Middle Eastern market, the market opportunity to be able to enter this area is in addition.

To the need for quality products as well as food and beverage products labeled "halal". To realize the strengthening of the competitiveness of food and beverage products while increasing the performance of the Indonesian food and beverage industry, it turns out that the government has carried out many policy steps, but in its implementation it has not been optimal. Some steps and efforts made include the development of small and medium industries in the food and beverage industry sector through increasing the technological capabilities of the food and beverage industry. Another step is to improve the structure of the food and beverage industry both from upstream to downstream, including in terms of concentration of market control and supplier network of raw materials, supporting materials, components, and semi-finished goods. In addition, continued administration optimization, investment and tax incentives in the food and beverage industry such as tax holiday, tax allowance, also synchronized various regulations related to the food and beverage industry sector.

\section{References}

Ardi, A., Waris, M. \& Ulin, N. (2012). The Impact of Trade Liberalization to Labor Absorption of Food Beverage Industry in Indonesia), Buletin Ilmiah Litbang Perdagangan, 6(2).

Hanani, N., R., HartonoLuh, P. A. \& Arnani. (2009). Analisis Tingkat Daya Saing Ekspor Buah-buhan Indonesia (Analysis of the Level of Competitiveness of Indonesian Fruit Exports), 8.

Kemenperin. (2012). Prospek dan Tren Minuman Ringan Indonesia Memasuki 2012. Food Review. Asosiasi Industri Minuman Ringan (Asrim)

Maradong, D. \& Setia. (2016). Potensi Besar Perikanan Tangkap Indonesia, Asisten Deputi Bidang Kelautan dan Perikanan, Deputi Bidang Kemaritiman. 
Ministry of Industry. (2017). Commitment to Increase Competitiveness of the Food and Beverage Industry.

Ministry of Industry. (2016). Study of Market Development of Export of Processed Food Products. Center for Foreign Trade Research and Development. Research and Development Agency.

Perumal, I., Uma, D. \& Krisnan. (2017). Social Media in Food and Beverages Industry: Case of Klang Valley, Malaysia. International Journal of Business and Management, 12(6).

Poeradisastra, F. (2012). Prospek dan Trend Industri Minuman Ringan Indonesia Memasuki 2012: Urbanisasi dan Kemakmuran? Food Review, Botani Square Bogor.

Porter, M., E. (2008). Strategy Bersaing (Competitive Strategy). Tangerang: Karisma Publishing Group.

Statistics Indonesia. (2018). Monthly Report of Socio Economic Data September 2019.

Wibowo, B. \& Adi, K. (2010). Menembus Pasar Ekspor, Siapa Takut, Penerbit PT Elek Media Komputindo, Jakarta.

World Economic Forum. (2017). The Global Competitiveness Index 2016-2017 Rankings, Klaus Schwab WEF, Geneva.

https://kfknowledgebank.kaplan.co.uk/porters-diamond-model- 